\title{
PEMBELAJARAN BAHASA ARAB INTERAKTIF MELALUI MEDIA E-LEARNING MADRASAH DI MTSN 1 KOTA MALANG
}

\author{
Siti Nurul Fitriani*1, Syarifah' ${ }^{1}$, Ali Susanto ${ }^{1}$ \\ 1Pendidikan Bahasa Arab UIN Maulana Malik Ibrahim Malang
}

\begin{abstract}
This paper aims to describe the use of Madrasah E-Learning as a modern learning Arabic with an easy and fun application and includes four maharohs. To meet these objectives, researchers used descriptive qualitative research methods. The results are (1) Madrasah E-Learning is a modern Arabic learning that is used online in Distance Learning (2) Madrasah E-Learning provides several main Arabic learning menus such as Class Timeline, Video Conference, Minimum Completeness Criteria, Learning Plans, Teaching Materials, Associated Student Data, Class Attendance, Teacher`s Journal, Computer Based Test (CBT), Knowledge Assessment (KI3), Skill Assessment (KI4), Final Semester Assessment, Report Card Recapitulation, Student Activity Monitoring. The research method that researchers use in this research is qualitative method research.
\end{abstract}

\section{Keywords: Arabic Languange learning, E-Learning Covid-19}

\begin{abstract}
Abstrak: Tulisan ini bertujuan untuk mendeskripsikan penggunaan ELearning Madrasah sebagai pembelajaran modern bahasa Arab dengan aplikasi yang mudah dan menyenangkan serta mencakup empat maharoh. Untuk memenuhi tujuan tersebut penulis menggunakan metode penelitian deskriptif-kualitatif. Hasilnya adalah (1) E-Learning Madrasah merupakan pembelajaran modern bahasa Arab yang digunakan secara daring pada Pembelajaran Jarak Jauh (2) E-Learning Madrasah menyediakan beberapa main menu pembelajaran bahasa Arab seperti Timeline Kelas, Video Conference, KriteriaKetuntasan Minimum, RencanaPembelajaran, Bahan Ajar, Data SiswaTergabung, Absensi Kelas, Jurnal Guru, Computer Based Test (CBT), PenilaianPengetahuan (KI3), Penilaian Keterampilan (KI4), Penilaian Akhir Semester, Rekap Nilai Rapor, Monitoring Aktifitas Siswa.
\end{abstract}

Kata Kunci: Pembelajaran Bahasa Arab, E-Learning Covid-19

*Korespondensi Penulis: sitinurulfitriani77@gmail.com 


\section{A. Pendahuluan}

Pada era industry 4.0 saat ini, perkembangan teknologi memiliki peran dan pengaruh yang cukup besar terhadap proses pembelajaran dan pengajaran untuk mengakses pengetahuan yang ingin dicari, terlebih kondisi saat ini yang mengharuskan para pendidik dan peserta didik melakukan proses pembelajaran melalui daring atau online. Akses teknologi juga mampu meningkatkan pendidikan karena tidak ada batasan dalam mencari informasi yang ingin diketahui. Sejak ditemukannya teknologi internet, para pendidik dan peserta didik lebih mudah mencari informasi, dan hampir segalanya menjadi mudah dalam dunia pendidikan. Menurut Keengwe \& Geornia dalam penelitiannya, menerangkan jika perkembangan teknologi saat ini memberikan transformasi terhadap penerapan pengajaran serta pembelajaran. ${ }^{1}$ Dan penerapan pembelajaran menggunakan media e-leaning adalah suatu inovasi yang dapat digunakan dalam proses pembelajaran.$^{2}$

Ditengah pendemi seperti saat ini, penggunaan e-learning dinilai sangat cocok untuk digunakan para peserta didik dan pendidikdalam menggunakan fasilitas system electronic learning yang ada atau yang sudah disediakan. Elearning sendiri kini semakin dikenal sebagai salah satu cara untuk mengatasi masalah pendidikan dan pelatihan, baik di negara-negara maju maupun di negaranegara yang sedang berkembang, khususnya Indonesia.

E-learning dibandingkan dengan media online lainnya dianggap lebih efektif dan efesien dalam melaksanakan pembelajaran, karena e-learning memiliki fiturfitur yang lengkap untuk memudahkan proses pembelajaran. E-learning secara general mempunyai dua pendapat dasar, yaitu: 1) Electronic Based E-learning

1 Jared Keengwe and David Georgina, "The Digital Course Training Workshop for Online Learning and Teaching," Education and Information Technologies 17, no. 4 (2012): 365-79.

2 Adam Ahmad Syahrul Alim and Abdulloh Hamid, "Efektivitas Sistem E-Learning Quipper School Pada Mata Pelajaran Bahasa Arab Kelas X MA Ihyaul Ulum Gresik," Al-Fikr: Jurnal Pendidikan Islam 6, no. 1 (2020): hlm. 35. 
merupakan pendidikan atau pembelajaran yang memamfaatkan teknologi informasi (internet), komunikasi dan elektronik. Artinya, dalam pemanfaatan teknologi serta komunikasi diperlukan pula memakai yang namanya elektronik. Seperti vidio, audio, film, kaset, LCD, projector, slide dll. 2) Internet Based merupakan pendidikan atau pembelajaran yang memanfaatkan fasilitas internet yang bersifat online. Maksudnya pembelajaran yang dilaksanakan menggunakan akses yang tidak terbatas jarak, ruang serta waktu. Salah satu Electronic Based Elearning, yaitu video based learning, terbukti telah menjadi trend pembelajaran. ${ }^{3}$

Ada juga yang mendefinisikannya dengan dibagi dari 2 bagian, ialah "E” yang singkatan dari electronica serta "Learning" yang maksudnya pendidikan. Jadi Elearning ialah teknologi informasi dan komunikasi untuk siswa yang ingin belajar kapanpun dan dimanapun. ${ }^{4}$ Tidak hanya itu, ada juga yang menguraikan tentang definisi e- learning dengan lebih luas lagi. Sebenarnya pada materi e- learning tidak wajib di distribusikan secara online baik lewat jaringan local maupun intemet. Interaksi dengan memanfaatkan internet ini dapat dilaksanakan secara online serta real time maupun secara offline ataupun archieved. Distribusi secara offline memanfaatkan media CD/ DVD juga yang tercantum pada e- learning.

Peraturan Menteri Pendidikan serta Kebudayaan No 109 tahun 2013, pembelajaran secara elektronik ( e- learning) yakni pembelajaran yang memakai paket informasi berbasis teknologi data dan komunikasi untuk kepentingan peserta didik agar dapat diakses oleh semua peserta didik kapan saja dan dimana saja. Terlebih keadaan seperti saat ini yang tidak memperbolehkan melakukan proses pendidikan disekolah dengan tatap muka secara langsung. Maka e-learning

3 Hesty Maulida Eka Putry et al., "Video Based Learning Sebagai Tren Media Pembelajaran Di Era 4.0," Tarbiyatuna: Jurnal Pendidikan Ilmiah 5, no. 1 (2020): 1-24.

4 Shashi Dahiya et al., "An ELearning System for Agricultural Education," Indian Research Journal of Extension Education 12, no. 3 (2016): 132-35. 
dinilai sangat efisien untuk digunakan agar tetap melakukan proses belajar mengajar. ${ }^{5}$

Beragam definisi tentang e- learning sepertiyang telah dipaparkan diatas, tetapi pada dasarnya disepakati bahwa e-learning merupakan pendidikan atau pembelajaran yang menggunakan teknologi elektronik untuk fasilitas penyajian serta distribusi data (informasi). Hal ini media serta materi belajar di kembangkan berdasarkan dengan kebutuhan peserta didik. Pembelajar bisa memakai CD/ DVD tersebut serta belajar ditempat dimana peserta didik terletak( Lukmana, 2006).

Sejak wabah pandemi Covid-19 melanda negara kita, pelaksanaan pembelajaran bergeser pola dari tatap muka secara langsung di sekolah menjadi pembelajaran daring (dalam jaringan) atau dikenal dengan Pembelajaran Jarak Jauh dengan cara belajar melalui jaringan online seperti aplikasi youtube, whatsapp, google classroom dan e-learning.

Salah satu terobosan yang dilakukan oleh pemerintah, terutama Kementerian Agama adalah dengan dilaunchingkannya program E-Learning Madrasah dalam pelaksanaan pembelajaran pada masa pandemi Covid-19ini.ELearning Madrasah merupakan salah satu langkah yang dilakukan oleh Kementerian Agama untuk memfasilitasi pelaksanaan pembelajaran di madrasahmadrasah yang berada di bawah naungannya agar pembelajaran tetap berjalan kapanpun, dimanapun dan dalam kondisi apapun secara efektif dan efesien termasuk MTsN 1 Kota Malang dalam pelaksanaan pembelajaran Bahasa Arab.

Sejalan dengan hal itu dua pertanyaan dirumuskan: (a) Fitur apa saja yang digunakan pembelajaran Bahasa Arab dalampenggunaan media E-Learning di MTsN 1 kota Malang? (b) Bagaimana proses pembelajaran Bahasa Arab dengan menggunakan media E-Learning di MTsN 1 kota Malang?

Tulisan ini didasarkan argumen bahwa pembelajaran melalui Pembelajaran Jarak Jauh (PJJ) dengan menggunakan E-Learning Madrasah dapat dilaksanakan

5 "E-Learning Madrasah Official," https://elearning.kemenag.go.id/, accessed December 29, 2020, https://elearning.kemenag.go.id/web. 
secara interaktif dengan berbagai fitur yang ada di dalamnya. Penggunaan ELearning Madrasah sangat efektif dan efisien digunakan dalam pembelajaran pada saat pandemi Covid-19 seperti ini karena di dalamnya memuat berbagai fitur yang mencakup keseluruhan dari maharah berbahasa (Istima`, Kalam, Qiro'ah, dan Kitabah). Sehingga tidak menghalangi peserta didik untuk belajar secara aktif dan interaktif dan semua kebutuhan peserta didik tersedia dalam fitur E-Learning Madrasah sehingga peserta didik tetap dapat meningkatkan kemampuan berbahasa mereka. Tujuan dari tulisan ini untuk mengetahui fitur-fitur yang digunakan dalam pembelajaran Bahasa Arab pada penggunaan media E-Learning Madrasah di MTsN 1 Kota Malang, dan untuk mengetahui proses pembelajaran Bahasa Arab dengan menggunakan media E-learning di MTsN 1 Kota Malang.

\section{B. Kajian Literatur}

\section{Penggunaan E-Learning Madrasah}

Penggunaan internet pada pembelajaran sangat diperlukan, terlebih pada kondisi pandemic seperti saat ini agar pembelajaran lebih efektif dan peserta didik dapat terus menggali ilmu, hal ini tidak lepas dari karakteristik internet yang khas, sehingga diharapkan dapat menunjang proses kegiatan belajar mengajar secara daring.Dalam pelaksanaan teknologi seperti ini, pemakaian e-learning, membutuhkan formulasi dengan strategi yang jelas untuk menjadi acuan. Penataan strategi e-learning semacam di informasikan. ${ }^{6}$ Agar bermanfaat untuk, memperjelas tujuan pelatihan ataupun pembelajaran yang ingin dicapai.

Dengan penggunaan e-learning madrasah, selain memberikan kemudahan terlaksananya proses belajar mengajar pada masa pandemic seprti saat ini, juga akan memberikan kesempatan yang lebih luas kepada para pendidik dalam berkreasi atau meningkatkan kualitas pembelajarannya dengan menciptakan berbagai materi serta meningkatkan kualitas dan kemampuan dalam mengajar

\footnotetext{
${ }^{6}$ Empy Effendi and Hartono Zhuang, E-Learning Konsep Dan Aplikasi (Yogyakarta: Penerbit Andi, 2005), hlm. 577.
} 
Bahasa Arab. Dalam pembelajaran melaui e-learning madrasah, pendidik juga dituntut untuk menciptakan teknik mengajar yang baik dan bahan ajar yang menarik serta menggunakan media yang bervariasi agar peserta didik lebih antusias dan tidak merasa bosan dalam belajar sehingga peserta didik lebih aktif dalam mengikuti pembelajaran.

\section{Syarat-syarat pemanfaatan E-Learning Madrasah}

E- learning sendiri memiliki syarat- syarat pemanfaatannya, Bagi Newsletter of ODLQC, 2001, ${ }^{7}$ syarat- syarat kegiatan elektronik dalam pembelajaran atau pendidikan ( e- learning) ialah:

a. Kegiatan belajar mengajar dicoba lewat pemakaian jaringan internet.

b. Tersedianya layanan belajar yang bisa digunakan oleh peserta didik, contohnya semacam CD- ROM ataupun bahan cetak.

c. Terdapatnya layanan tutor ataupun pengajar yang bisa memudahkan peserta didik apabila menghadapi kesusahan.

d. Terdapatnya lembaga ataupun lembaga yang menyelenggarakan serta mengelola aktivitas e- learning.

e. Mempunyai perilaku positif pendidik serta tenaga kependidikan terhadap teknologi pc serta internet.

f. Terdapatnya rancangan system pendidikan yang bisa dipelajari oleh setiap peserta didik.

g. Terdapatnya penilaian buat kemajuan ataupun pertumbuhan peserta didik.

Tenaga-tenaga ahli untuk menghidupkan sebuah e-learning. salah satunya yaitu:

a. Subject Matter Expert (SME), adalah narasumber dari pembelajaran yang disampaikan.

b. Intructional Designer (ID), bekerja secara sistematis mendesain materi dari SME menjadi materi e-learning dengan menerapkan metode pengajaran yang mudah agar materi menjadi lebih interaktif.

c. Learning Management System (LSM), bertugas mengelola sistem di website yang mengatur lalu lintas interaksi antara pengajar dengan siswa, atau siswa dengan siswa.

7 Sudirman Siahaan, "Penelitian Penjajagan Tentang Kemungkinan Pemanfaatan Internet Untuk Pembelajaran Di SLTA Di Wilayah Jakarta Dan Sekitarnya," Jurnal Pendidikan Dan Kebudayaan. Halaman, 2002, 784-808. 
Dan pada penggunaan E-Learning dalam Pembelajaran,mempunyai beberapa hal yang harus dipertimbangkan yaitu, (1) Analisis Kebutuhan, pada tahap ini perlu dipertimbangkan apakah penggunaan E-Learning dalam pembelajaran dibutuhkan? Dari analisis inilah nantinya diputuskan apakah perlu atau butuh menggunakan E-Learning dalam pelaksanaan pemblajaran. Jika iya, perlu adanya kelayakan yang harus diperhatikan dalam penggunaannya antara lain: a. apakah perangkat dan tenaga teknis dapat dipasang dan tersedia? b. apakah secara ekonomi menguntungkan atau apakah return on investment nya lebih besar, c. apakakah penggunaan E-Learning menguntungkan.(2) Rancangan Instruksional, hal yang perlu diperhatikan pada tahapan ini adalah aspek course content and learning unit analysis, seperti latar belakang Pendidikan peserta didik, usia, status pekerjaan, dan sebagainya. (3) Tahap Pengembangan, pengembangan E-Learning dilaksanakan berdasarkan pengembangan ICT yang tersedia.(4)Pelaksanaan, prototype yang lengkap bisa dipindahkan ke komputer (LAN) dengan menggunakan format misalnya fornat HTML. Dan apakah bahan ajar sesuai dengan standart bahan ajar. (4) Evaluasi, Melakukan evaluasi secara terus menerus dengan bantuan beberapa orang untuk ikut dalam pelaksanaan evaluasi.

\section{Keunggulan E-Learning Madrasah}

Dalam pembahasan ini, E-learning Madrasah yang digunakan yaitu website pembelajaran yang dirancang khusus oleh Kementerian Agama untuk pelaksanaan pembelajaran pada masa pandemi Covid-19 secara mandiri dalam pengawasan Kementerian Agama, madrasah, guru dan orang tua peserta didik.Dalam e-learning madrasah ini memiliki beberapa fitur di dalamnya yang dapat digunakan untuk menunjang pembelajaran Bahasa Arab yang mencakup empat maharoh, yaitu istima', kalam, qiro'ah dan kitabah. E-learning sendiri dinilai dapat merubah suasana baru dalam ragam pengembangan pembelajaranatau dunia pedidikan. Pemanfaatan e-learning dengan baik dapat meningkatkan hasil pembelajaran 
dengan maksimal. ${ }^{8}$ E-learning ini memiliki beberapa keunggulan, diantaranya: a) laman websitenya dapat diakses dari komputer, laptop maupun ponsel, b) laman di akses tanpa batasan ruang, waktu dan tempat. Jadi dapat diakses dimanapun dan kapanpun, c) laman in dapat memuat berbagai fitur/menu yang dapat menunjang pelaksanaan Pembelajaran Jarak Jauh (PJJ), d) Pengguna dapat mengakses dengan mudah tanpa akun, e) setiap pengguna mempunyai username dan password sendiri-sendiri, sehingga dijamin keamanan datanya, f) pendidik lebih aktif dan kreatif dalam pelaksanaan pembelajaran, g) sebagai sarana komunikasi antara pendidik dan peserta didik secara virtual, h) alat kontrol keaktifan peserta didik dalam belajar. I) sarana penyampaian materi oleh pendidik kepada peserta didik dan j) menampung semua tugas peserta didik, baik berupa word, pdf, dan video.

Adapun tujuan dan manfaat dari penggunaan e-learning adalah sebagai berikut, (a) Sebagai media untuk peningkatan kualitas pelaksanaan proses belajar peserta didik, (b) Terjadinya perubahan dari pembelajaran pasif menjadi pembelajaran aktif bagi peserta didik, (c) Mengubah cara atau budaya pengajaran pendidik, (d) Dapat memberikan kesempatan belajar kepada masyarakat lebih luas, (e) Memperluas dan mengembangkan produk dan layanan baru. ${ }^{9}$ Manfaat penggunaan E-Learning dalam Pembelajaran: (a) Adanya peningkatan mutu pembelajaran pendidik dan peserta didik, (b) Pembelajaran tidak dibatasi oleh ruang dan waktu karena pelaksanaan pembelajaran tidak berpusat pada pertemuan tatap muka, (c) Materi disampaikan melalui e-learning, sehingga mudah diakses dan dikembangkan oleh peserta didik, (d) Penyampaian materi atau pengayaan materi yang disampaikan kepada peserta didik disesuaikan dengan kemajuan ilmu pengetahuan, perkembangan ilmu pengetahuan dan kemajuan teknologi, (e) Menciptakan competitive positioning dan meningkatkan

${ }^{8}$ Lailatu Rohmah, "Konsep E-Learning Dan Aplikasinya Pada Lembaga Pendidikan Islam," An-Nur: Jurnal Studi Islam 3, no. 2 (2016).

${ }^{9}$ Hujair AH Sanaky, Media Pembelajaran (Yogyakarta: Safiria Insania Press, 2009), hlm. 204-205. 
brand image,(f) Meningkatkan kualitas dari pembelajaran dan pelayanan pembelajaran serta kepuasaan pendidik, (g) Mengurangi biaya operasi dan dapat meningkatkan pendapatan, (h) Dapat meningkatkan interaktivitas pembelajaran, karena tidak ada batasan ruang dan waktu dalam belajar, dan (i) Learning Oriented, sehingga pendidik lebih bertanggungjawab atas kesuksesannya dalam belajar. Dan ada 3 model alternatif dalam kegiatan pembelajaran; yaitu: a. Tatap muka penuh (konvensional), b. separuh dengan menggunakan carat atap muka dan Sebagian menggunakan internet, c. menggunakan internet secara full. ${ }^{10}$

\section{Karakteristik E-Learning}

Pada proses pembelajaran yang menggunakan media e-learning, memiliki beberapa masalah yang sering dihadapi seperti, ketersediaan akses atau jaringan internet, ketersediaan peranti lunak (software), ketersediaan peranti lunak yang tidak mahal, bagaimana dampaknya terhadap pelaksanaan implementasi kurikulum dan masalah knowledge dan skill. ${ }^{11}$

Rosenberg (2001) ${ }^{12}$ menjelaskan ada tiga kriteria dalam E-Learning, Bersifat jaringan, Yaitu mampu memperbaiki secara cepat, menyimpan atau memunculkan kembali, mendistribusikan, dan sharing pembelajaran dan informasi. (2) E-learning dikirimkan kepada pengguna melalui komputer dengan menggunakan standar teknologi internet. CD ROM, Web TV, Web Cell Phones, agers, (3) e-learning terfokus pada pandangan pembelajaran yang paling luas.

10 Sri Rahayu Chandrawati, “Pemanfaatan E-Learning Dalam Pembelajaran,” Jurnal Cakrawala Kependidikan 8, no. 2 (2010): 218616.

11 Hamonangan Tambunan, "Pemanfaatan E-Learning Dalam Pembelajaran," Jurnal Teknologi Pendidikan 4, no. 01 (2011): 104-13.

12 Dalam Dwi Heri Sudaryanto, "Pemanfaatan E-Learning Sebagai Media Pembeljaran Mandiri," Swara Patra 6, no. 4 (2016). 
E- learning sendiri memiliki syarat- syarat pemanfaatannya, Bagi Newsletter of ODLQC, 2001, ${ }^{13}$ syarat- syarat kegiatan elektronik dalam pembelajaran atau pendidikan ( e- learning) ialah: Kegiatan belajar mengajar dicoba lewat pemakaian jaringan internet, tersedianya layanan belajar yang bisa digunakan oleh peserta didik, contohnya semacam CD- ROM ataupun bahan cetak. terdapatnya layanan tutor ataupun pengajar yang bisa memudahkan peserta didik apabila menghadapi kesusahan, terdapatnya lembaga ataupun lembaga yang menyelenggarakan serta mengelola aktivitas e- learning, dan mempunyai perilaku positif pendidik serta tenaga kependidikan terhadap teknologi pc serta internet.

Dalam pembahasan ini, E-learning Madrasah yang digunakan yaitu website pembelajaran yang dirancang khusus oleh Kementerian Agama untuk pelaksanaan pembelajaran pada masa pandemi Covid-19 secara mandiri dalam pengawasan Kementerian Agama, madrasah, guru dan orang tua peserta didik.Dalam e-learning madrasah ini memiliki beberapa fitur di dalamnya yang dapat digunakan untuk menunjang pembelajaran Bahasa Arab yang mencakup empat maharoh, yaitu istima', kalam, qiro'ah dan kitabah. E-learning sendiri dinilai dapat merubah suasana baru dalam ragam pengembangan pembelajaranatau dunia pedidikan. Pemanfaatan e-learning dengan baik dapat meningkatkan hasil pembelajaran dengan maksimal. ${ }^{14}$ E-learning ini memiliki beberapa keunggulan, diantaranya:1) Laman websitenya dapat diakses dari komputer, laptop maupun ponsel, 2) laman di akses tanpa batasan ruang, waktu dan tempat. Jadi dapat diakses dimanapun dan kapanpun, 3)laman in dapat memuat berbagai fitur/menu yang dapat menunjang pelaksanaan Pembelajaran Jarak Jauh (PJJ), 4) pengguna dapat mengakses dengan mudah tanpa akun.

Penilaian dalam penggunaan e-learning dapat dilihat dari perkembangan yang telah di ikuti siswa selama proses pembelajaran berlangsung maka semua nilai hasil dari pembelajaran di rangkum menjadi satu, yaitu meningkat

13 Siahaan, "Penelitian Penjajagan Tentang Kemungkinan Pemanfaatan Internet Untuk Pembelajaran Di SLTA Di Wilayah Jakarta Dan Sekitarnya."

${ }^{14}$ Rohmah, "Konsep E-Learning Dan Aplikasinya Pada Lembaga Pendidikan Islam." 
keterampilan siswa dalam mengerjakan tugas-tugas yang di berikan guru, yang mengacu pada Pengetahuan (KI-3), Keterampilan(KI-4), Penilaian Akhir Semester yang semakin meningkat dibuktikan dengan Rekap Nilai Rapor, Monitoring Aktifitas Siswa yang lebih terkontrol dikarenakan selalu dalam pengawasan orang tua, guru dan pihak sekolah. Beberapa karakteristik dari E-learning antara lain:

a. Menggunakan jasa teknologi elektronik sehingga bisa memperoleh informasi dan melakukan komunikasi dengan lebih mudah dan cepat, baik itu antara pengajar dengan pembelajar, atau antar pembelajar dengan.

b. Menggunakan atau memanfaatkan media komputer.

c. Materi pembelajaran dapat dipelajari secara individu (self learning materials).

d. Materi yang sudah dijelaskan bisa disimpan di computer sehingga dapat diakses oleh pengajar maupun peserta didik kapan dan di mana saja.

e. Komputer dapat di manfaatkan sebagai suatu proses dalam pembelajaran serta dapat mengetahui hasil kemajuan belajar, dan juga administrasi pendidikan dapat diperoleh melalui informasi yang banyak dari berbagai sumber informasi.

\section{Metode Penelitian}

Tulisan ini mengkaji bagaimana pembelajaran Bahasa Arab di MTsN 1 Kota Malang yang biasanya menggunakan metode konvensional (tatap muka) secara langsung di dalam kelas, dengan adanya pandemi Covid-19 bergeser menjadi Pembelajaran Jarak Jauh (PJJ) secara online. Maka dari itu, penelitian ini menggunakan metode penelitian deskriptif-kualitatif, penelitian kualitatif dalam buku Albi Anggito dan Johan Setiawan mengatakan bahwa penelitian kualitatif adalah, penelitian yang menggunakan latar alamiah dengan maksud menafsirkan fenomena yang terjadi dan dilakukan dengan jalan melibatkan berbagai metode yang ada. Penelitian kualitatif sendiri tidak menggunakan statistik, tetapi melalui pengumpulan data, analisis kemudian di interprestasikan. ${ }^{15}$ Sumber data pada penelitian ini adalah, E-Learning Madrasah. Adapun tekhnik pengumpulam data dalam penelitian ini adalah dengan pengamatan atau observasi.

${ }^{15}$ Albi Anggito and Johan Setiawan, Metodologi Penelitian Kualitatif (CV Jejak (Jejak Publisher), 2018), hlm. 7. 


\section{Hasil dan Pembahasan}

\section{Fitur-Fitur pada E-Learning Madrasah dan Proses Pembelajaran Bahasa Arab di MTsN 1 Kota Malang}

E-learning madrasah mempunyai berbagai fitur yang dapat diakses penggunanya dalam pelaksanaan Pembelajaran Jarak Jauh, diantaranya: Timeline Kelas, Video Conference, Kriteria Ketuntasan Minimum, Rencana Pembelajaran, Bahan Ajar, Data Siswa Tergabung, Absensi Kelas, Jurnal Guru, Computer Based Test (CBT), Penilaian Pengetahuan (KI3), Penilaian Keterampilan (KI4), Penilaian Akhir Semester, Rekap Nilai Rapor, Monitoring Aktifitas Siswa. Gambar 1 menunjukkan tampilan menu/fitur dalam e-learning madrasah:

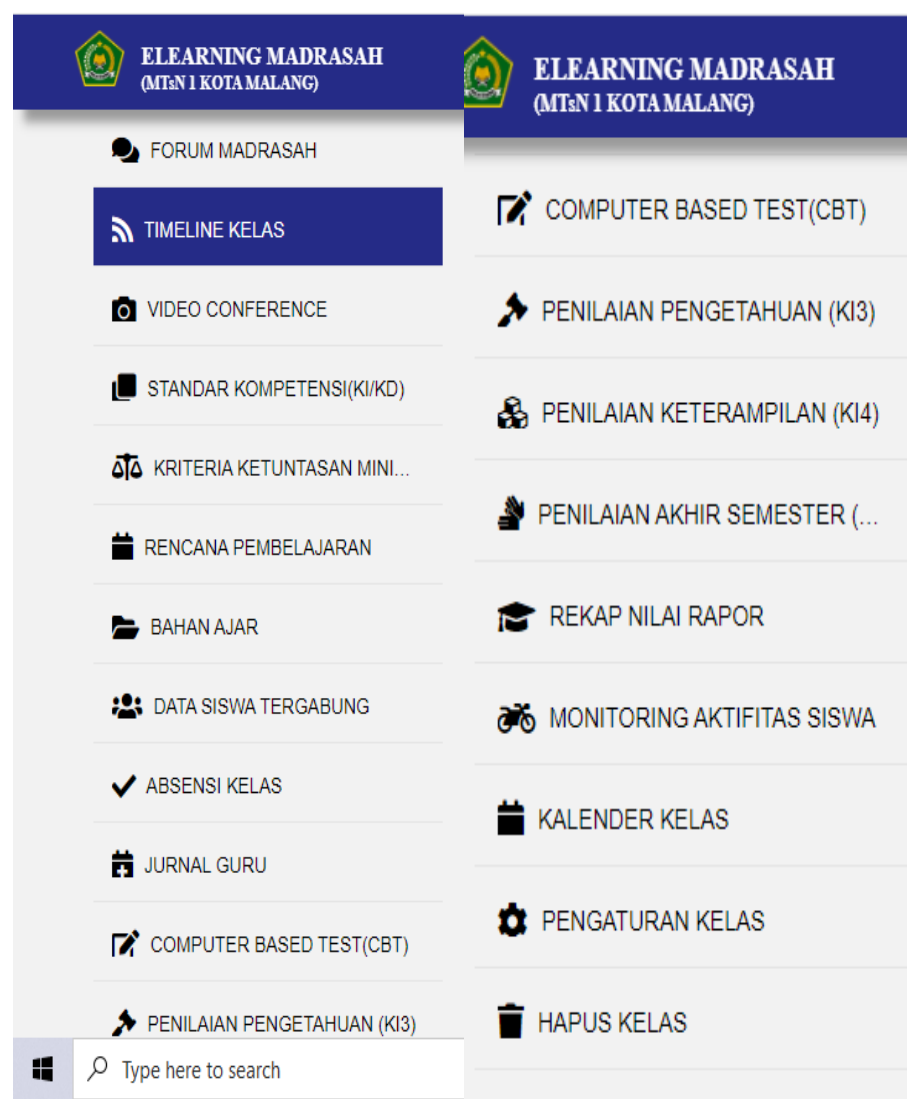

Gambar 1. Tampilan Fitur-Fitur pada E-Learning 


\section{Timeline Kelas}

Dalam Timeline, pendidik dapat menyapa dan menyampaikan agenda pembelajaran yang akan disampaikan kepada peserta didik. Dengan demikian, peserta didik dapat membaca, mengetahui dan menyiapkan apa saja yang akan dipelajari pada hari ini. Hal ini ditunjukkan sebagaimana gambar 2.

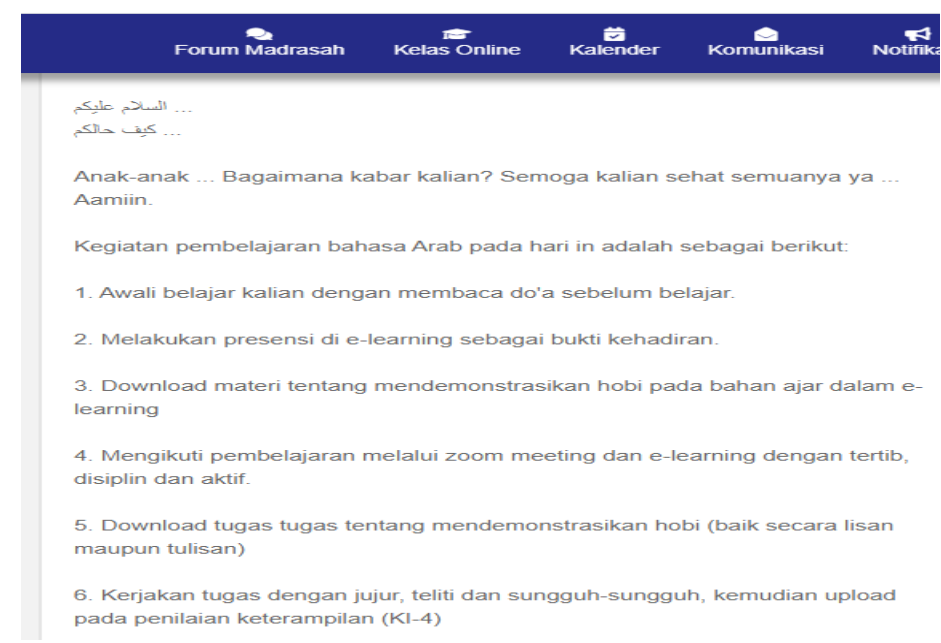

Gambar 2. Tampilan Timeline Kelas

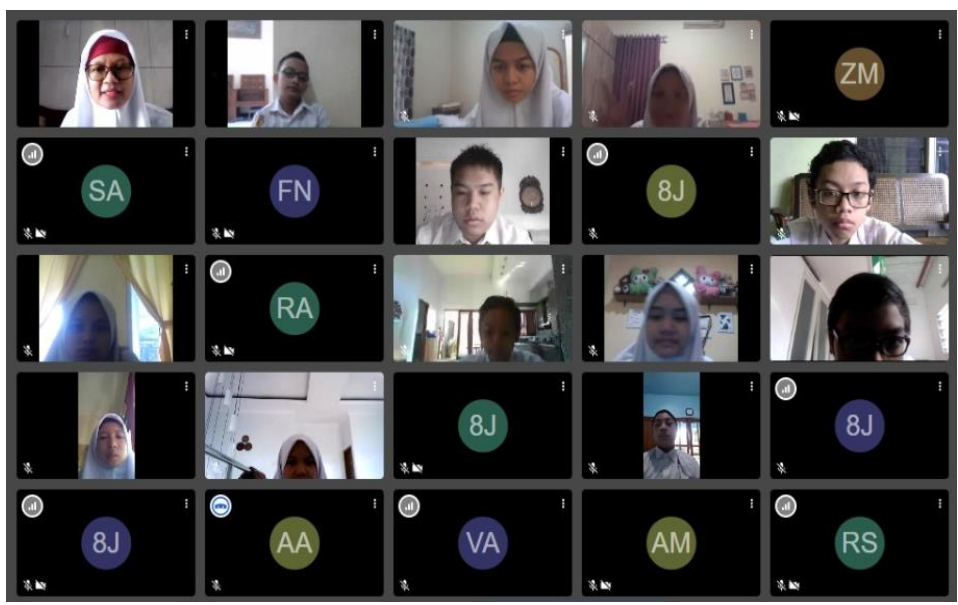

Gambar 3. TampilanVideo Conference 


\section{Video Conference}

Pada menu ini, pendidik dan peserta didik dapat melaksanakan pembelajaran dengan cara bertatap muka secara virtual, dengan melakukan Tanya jawab terkait pembelajaran yang sedang berlangsung. Hal ini tampak pada gambar 3.

\section{Standar Kompetensi}

Disini, pendidik menuliskan kompetensi apa saja yang harus dikuasai oleh peserta didik dalam pembelajaran Bahasa Arab yang sedang berlangsung. Sehingga dapat dijadikan acuan dalam penguasaan materi oleh peserta didik. Gambar 4 menunjukkan tampilan menu Standar Kompetensi.

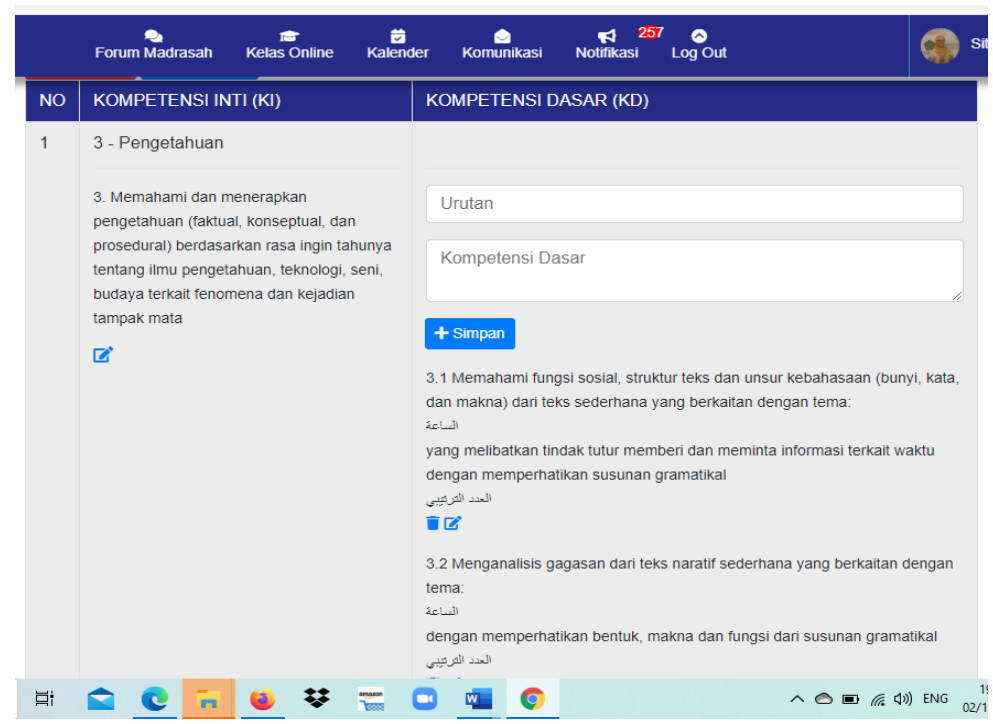

Gambar 4. Tampilan Fitur Standar Kompetensi

\section{Kriteria Ketuntasan Minimal (KKM)}

KKM dijabarkan pada setiap kompetensi, sehingga peserta didik dapat mengetahui berapa batas minimal kelulusan setiap kompetensi yang ditargetkan dalam pembelajaran. Gambar 5 menunjukkan bagaimana tampilan fitur ini. 


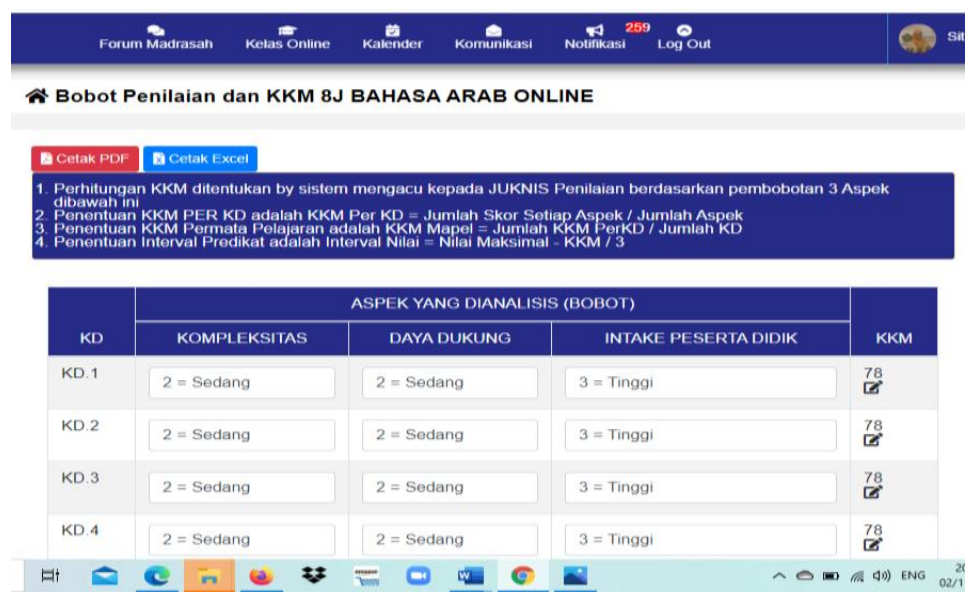

Gambar 5. Tampilan Fitur KKM

\section{Rencana Pembelajaran}

Dalam Rencana Pembelajaran, dijabarkan kapan (hari, tanggal, waktu) pembelajaran dilaksanakan, materi apa yang akan dipelajari, Kompetensi apa saja yang harus dikuasai peserta didik dalam pembelajaran tersebut, apa tujuan pembelajaran tersebut, metode apa yang digunakan dalam pembelajaran tersebut, media apa yang digunakan dalam penyampaian materi, sumber belajar apa yang digunakan, bagaimana langkah-langkah kegiatan pembelajaran akan dilaksanakan dan bagaimana system penilaiannya. Hal ini tampak pada gambar 6 .

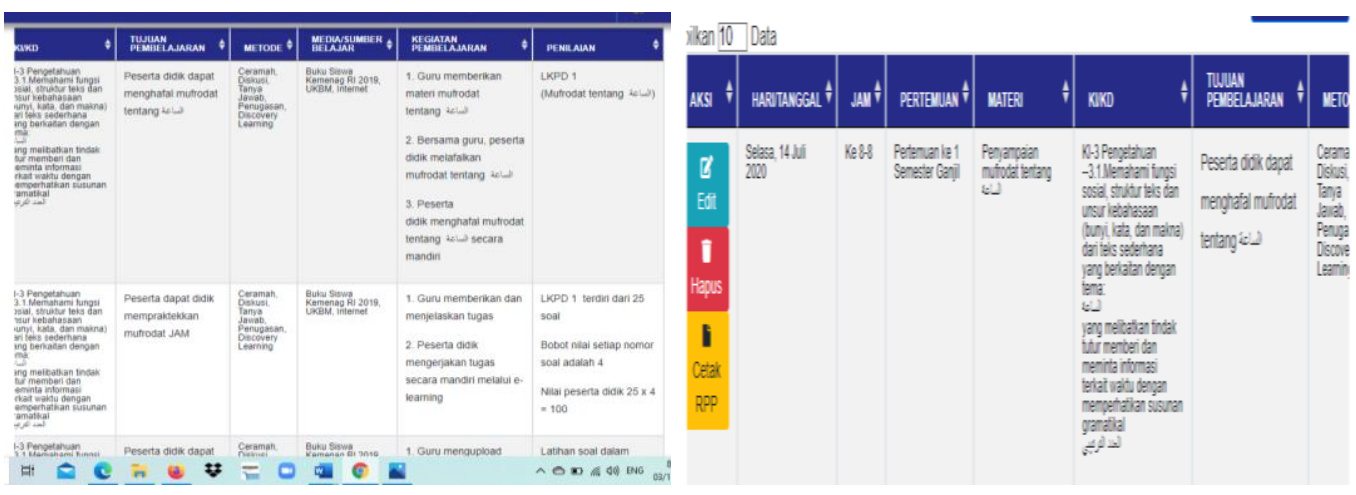

Gambar 6. Tampilan Rencana Pembelajaran

173 | Tarbiyatuna: Jurnal Pendidikan Ilmiah Vol. 5 No. 2 (Desember) 2020 
Siti Nurul Fitriani, Syarifah, Ali Susanto

\section{Bahan Ajar}

Bahan ajar, pendidik dapat mengupload materi yang akan dipelajari pada proses pembelajaran. Bahan ajar yang diupload bisa berupa word, pdf, excel, ppt, video, link dan gambar. Kemudian peserta didik dapat mendownload seluruh materi tersebut melalui e-learning masing-masing (Gambar 7).

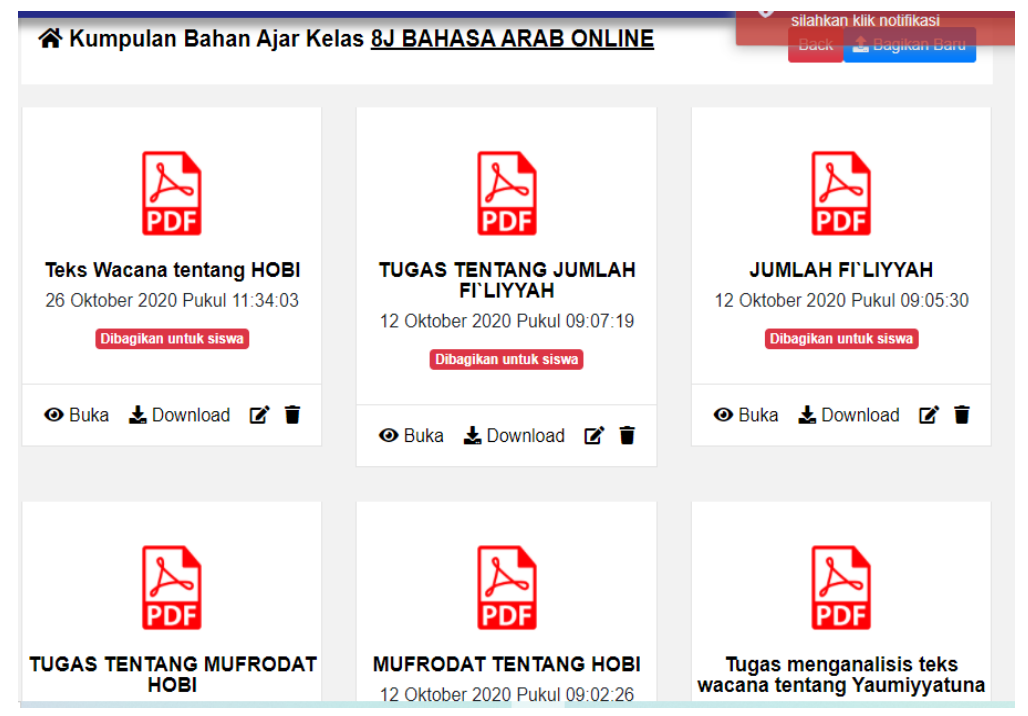

Gambar 7. Tampilan Fitur Bahan Ajar

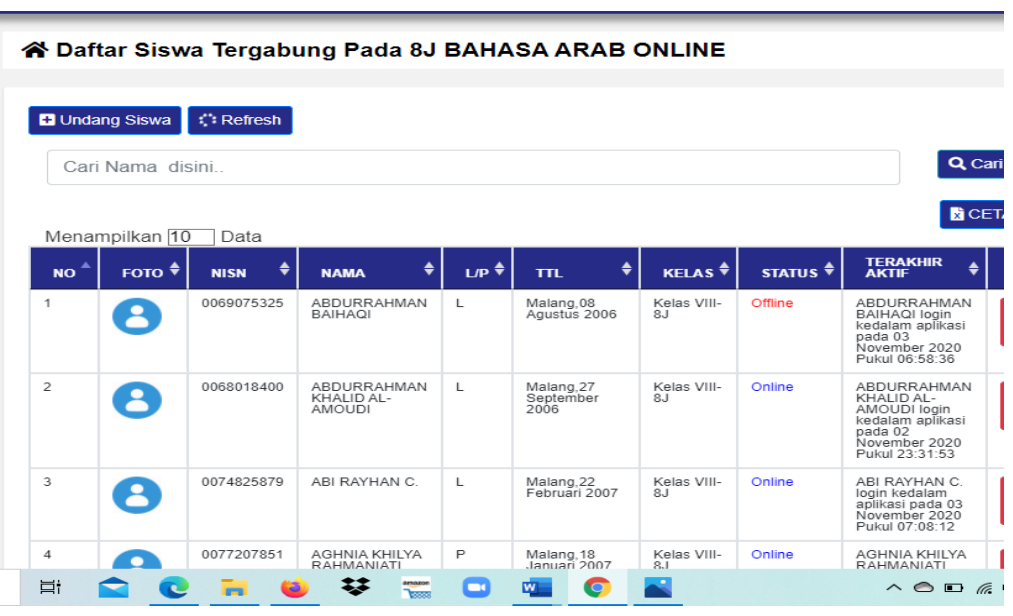

Gambar 8. Tampilan Daftar Siswa Tergabung

Tarbiyatuna: Jurnal Pendidikan Ilmiah Vol. 5 No. 2 (Desember) 2020| 174 


\section{Data Siswa Tergabung}

Dari data siswa tergabung ini, pendidik dapat mengetahui siapa saja pesertadidik yang online (sedang mengerjakan tugas yang telah diberikan melalui bahan ajar). Atau pendidik juga bisa mengetahui siapa saja yang tidak mengikuti pembelajaran online tersebut. Hal ini merupakan solusi pantauan pendidik kepada peserta didik dalam pelaksanaan pembelajaran. Tampak pada gambar 8.

\section{Absensi Kelas}

Presensi kehadiran peserta didik sesuai jadwal pelajaran masingmasing.Peserta didik melakukan presensi secara mandiri pada laman ini. Pendidik dapat mengecek kehadiran peserta didik pada laman ini, sebagaimana gambar 9.

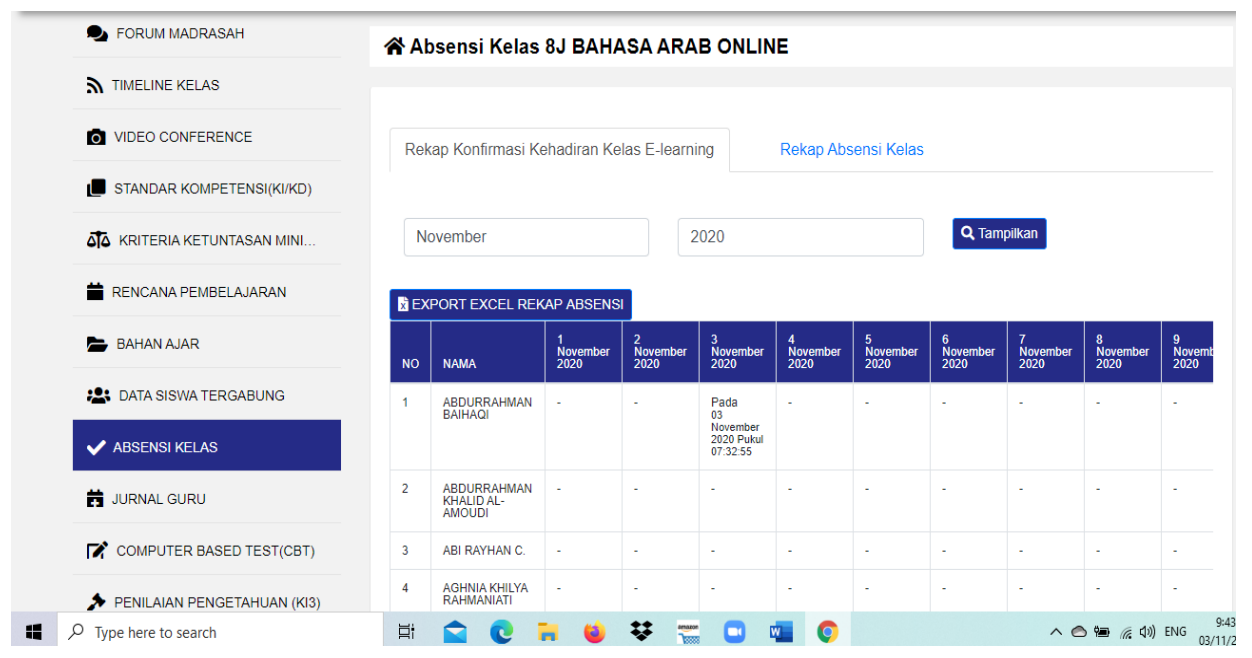

Gambar 9. Tampilan Absensi Kelas

\section{Jurnal Guru}

Di jurnal guru, pendidik dapat menuliskan kejadian apa yang terjadi pada peserta didik dan apa tindak lanjut yang dilakukan oleh pendidik untuk solusinya. Kemudian bekerjasama dengan wali kelas dan guru BK dalam memecahkan masalah yang dihadapi oleh peserta didik tersebut. Jadi peserta didik dapat terus dipantau perkembangannya. Hal ini tampak pada gambar 10. 
Siti Nurul Fitriani, Syarifah, Ali Susanto

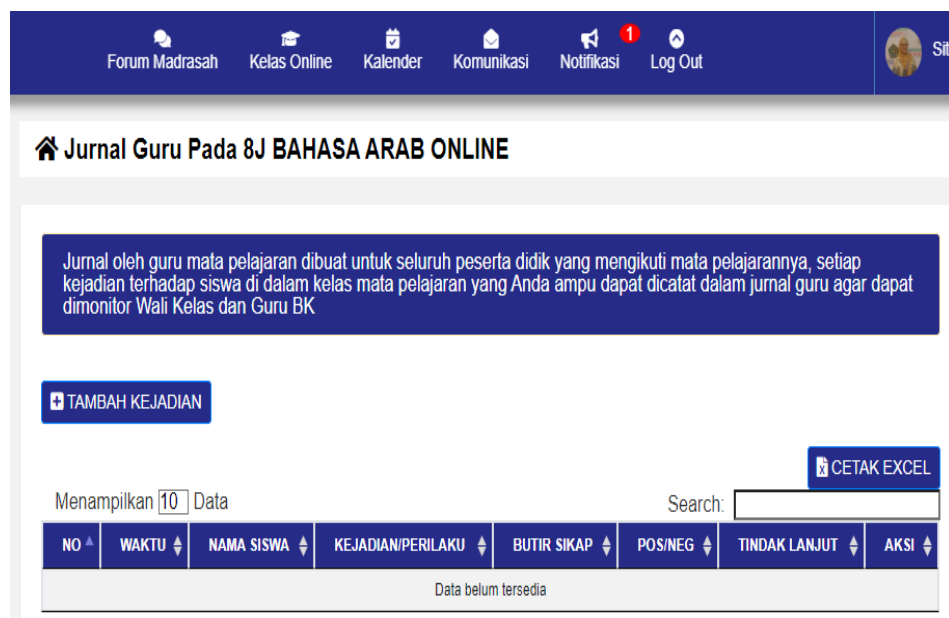

Gambar 10. Tampilan Jurnal Guru

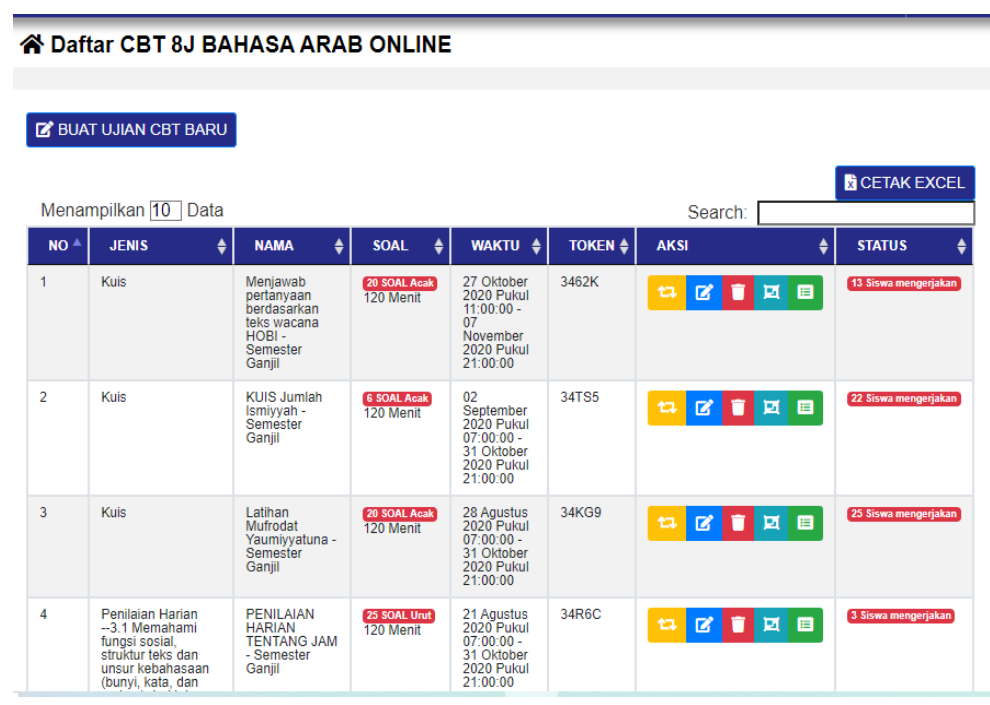

Gambar 11. Tampilan CBT

\section{Computer Based Test (CBT)}

Dalam CBT, pendidik dapat memberikan tugas kepada peserta didik dengan berbagai jenis penilaian, seperti kuis, penilaian harian dan penilaian akhir semester, serta dapat menggunakan variasi/model penilaian, seperti multiple 
choice, true false, menjodohkan, short answer dan essay. Dan hasil (nilai) peserta didik dapat langsung muncul/keluar, sehingga peserta dapat mengetahui secara langsung nilainya setelah mereka mengerjakan. Gambar 11 menunjukkan fitur ini.

\section{PenilaianPengetahuan (KI3)}

Pada fitur ini, pendidik dapat mengupload tugas yang akan diberikan dari aspek atau ranah pengetahuan peserta didik. Dalam penilaian ini dapat dijelaskan tugas ini diberikan pada pertemuan keberapa, skema penilaiannya bagaimana (tugas/kuis, tulis atau lisan), kompetensi yang harus dikuasai peserta didik apa, tugas ini termasuk penilain keberapa, instruksi penilaiannya bagaimana, kapan mulai pengerjaan tugas dan kapan batas pengerjaan tugas tersebut. Dalam penilaian ini, peserta didik dapat mengetahui hasil/nilai yang diperoleh setelah pendidik mengoreksi tugas peserta didik, serta pendidik dapat memberikan feed back dari tugas peserta didik yang telah dikoreksi. Gambar 12 merupakan tampilan dari fitur ini.

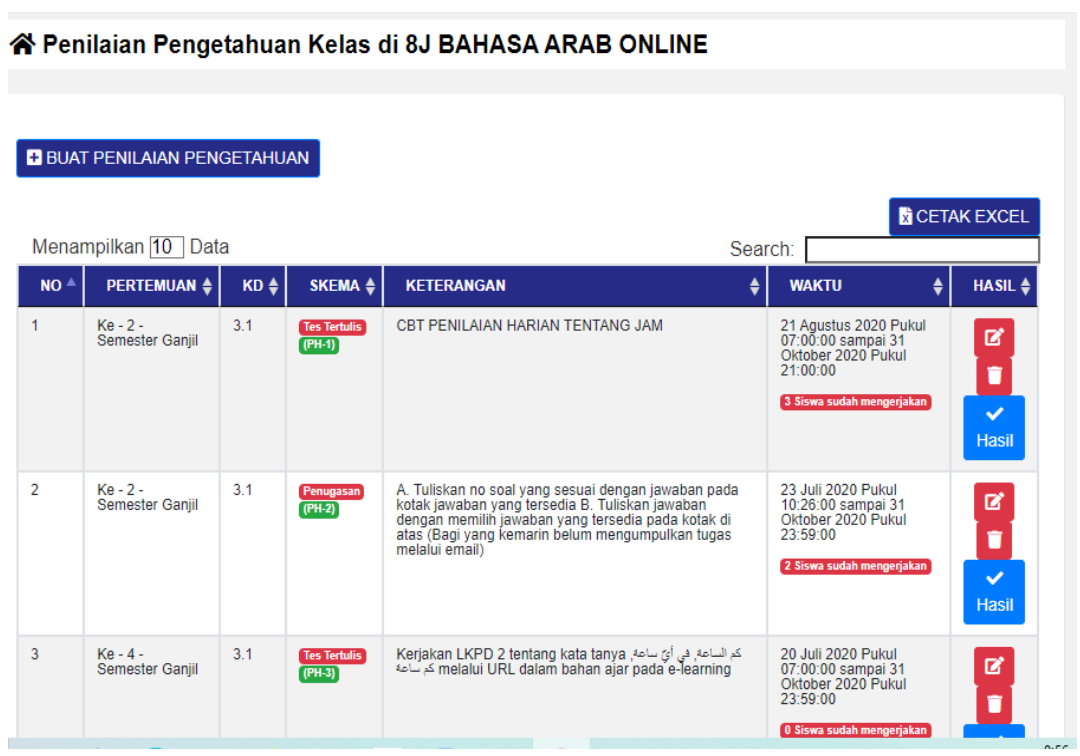

Gambar 12. TampilanPenilaianPengetahuan (KI-3) 
Pada laman ini, pendidik dapat mengembangkan maharoh Istima` dari video yang sudah diupload pada bahan ajar. Pendidik dapat memberikan tugas kepada peserta didik dengan cara menuliskan kata/kalimat yang ada pada video tersebut, atau menjawab pertanyaan berdasarkan video dan menuliskan kesimpulan dari video yang telah ditonton. Untuk Maharoh Qiro`ah, Pendidik dapat memberikan tugas yang terkait dengan teks wacana sederhana, menerjemah dan menjawab pertanyaan berdasarkan teks wacana. Sedangkan untuk kemahiran membacanya dapat dimasukkan pada penilaian keterampilan (KI4).

\section{Penilaian Keterampilan (K14)}

Skema penilaian pada penilaian keterampilan hampir sama dengan penilaian pengetahuan ,bedanya dalam penilaian keterampilan peserta didik dapat mengirimkan tugas mereka berupa video. Pada penilaian keterampilan (KI4), pendidik dapat memberikan tugas yang terkait dengan kemahiran kalam. Pendidik dapat memberikan tugas seperti pengiriman video terkait membaca teks wacana atau video yang mempraktekkan dialog dengan temannya dan video unjuk kerja, seperti bercerita tentang materi yang diajarkan. Hal ini tampak pada gambar 13 .

? Penilaian Keterampilan Kelas di 8J BAHASA ARAB ONLINE

† BUAT PENILAIAN KETERAMPILAN

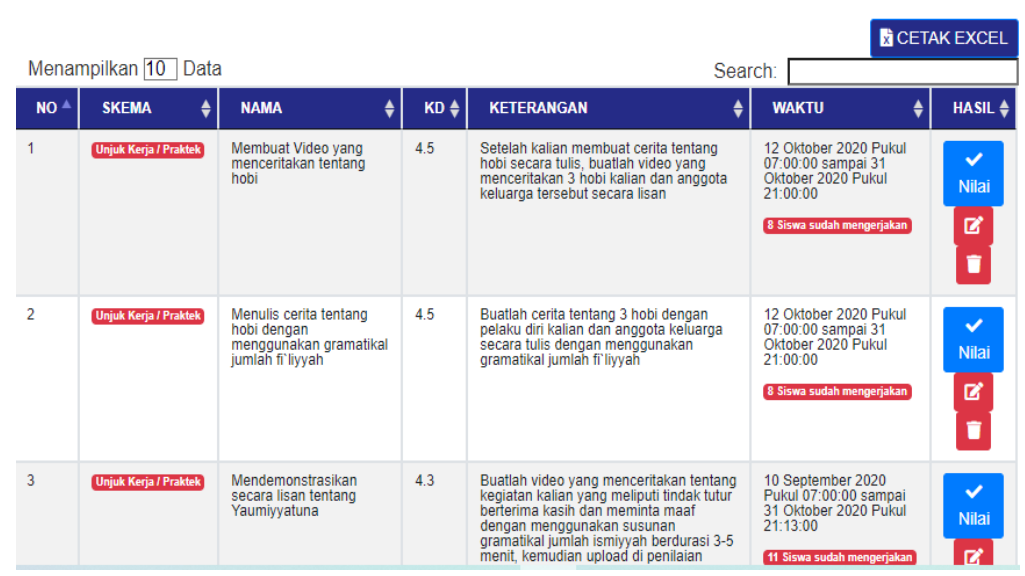

Gambar 13. Tampilan Penialaian Keterampilan (KI-4) 


\section{Penilaian Akhir Semester (PAS)}

Fitur ini merupakan rekap anda riber bagai penilaian yang telah dikerjakan oleh peserta didik selama satu semester dan nilai dari Penilaian Akhir Semester untuk dimasukkan ke dalam rapor. Hal ini tampak pada gambar 14.

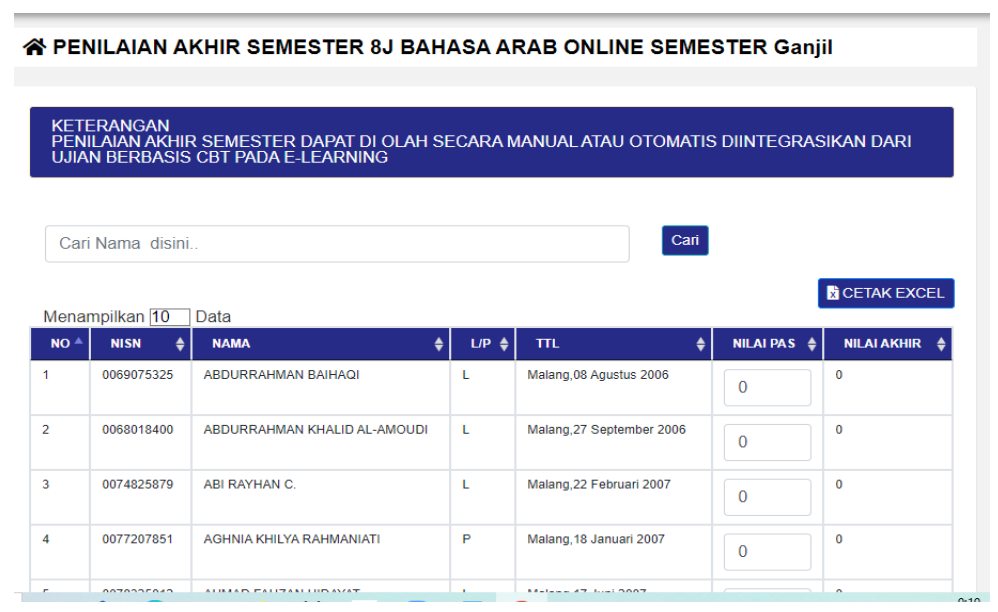

Gambar 14. Tampilan Penilaian Akhir Semester

\section{Rekap Nilai Rapor}

Ada rekap nilai rapor, di mana nilai diperoleh dari gabungan semua nilai dari seluruh kompetensi dasar yang sudah dikerjakan oleh peserta didik (Gambar 15).

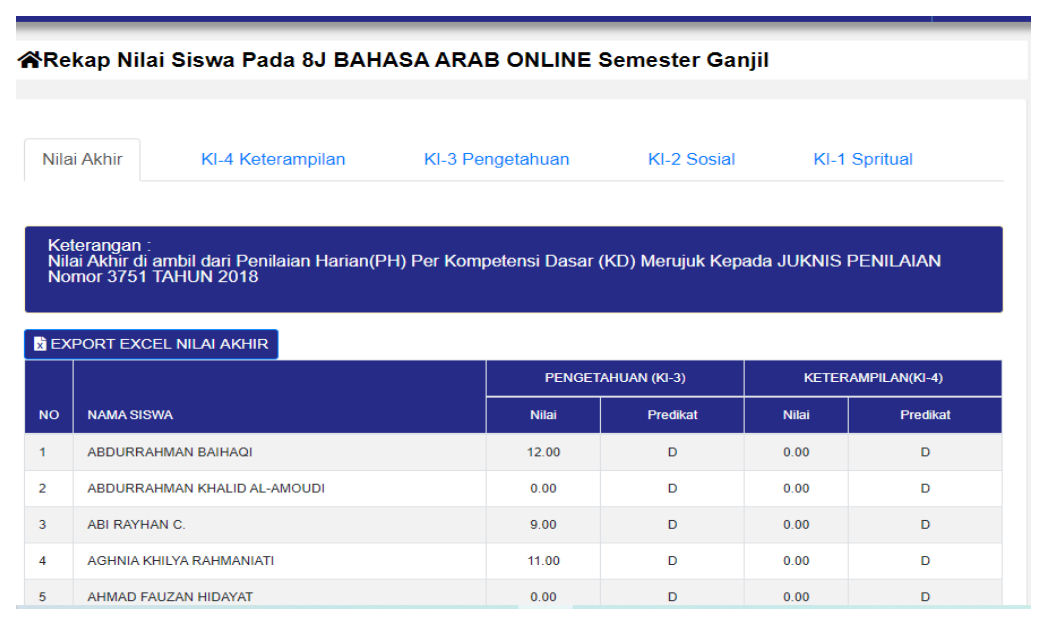

Gambar 15. Tampilan Rekap Nilai Rapor

179 | Tarbiyatuna: Jurnal Pendidikan Ilmiah Vol. 5 No. 2 (Desember) 2020 


\section{Monitoring Aktifitas Siswa}

Pendidik dapat mengetahui aktifitas peserta didik dalam e-learning tersebut, mulai dari peserta didik melakukan presensi, mendownload materi, mengerjakan tugas, dan mengirimkan tugas. Hal ini dapat dilihat sebagaimana gambar 15.

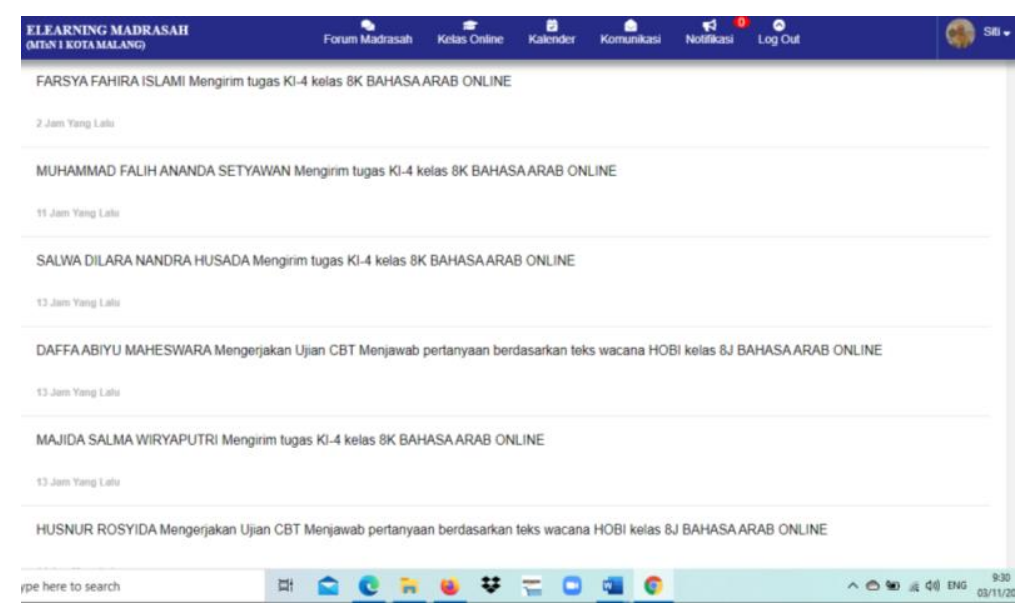

Gambar 16. Tampilan Monitoring Aktifitas Peserta Didik

\section{E. Kesimpulan}

Kemajuan teknologi pada zaman ini sangat mendukung untuk proes pembelajaran terlebih lagi pada kondisi saat ini pembelajaran melalui tatap muka atau langsung tidak diperbolehkan. Oleh karna itu pemerintah menetapkan proses pembelajaran harus melalui akses internet. Media yang digunakan dari beberapa sekolah adalah E-Learning. Hasil penelitian menunjukkan bahwa Fitur-fitur yang ada pada E-learning diantaranya: Timeline Kelas, Video Conference, Kriteria Ketuntasan Minimum, Rencana Pembelajaran, Bahan Ajar, Data Siswa Tergabung, Absensi Kelas, Jurnal Guru, Computer Based Test (CBT), Penilaian Pengetahuan (KI3), Penilaian Keterampilan (KI4), Penilaian Akhir Semester, Rekap Nilai Rapor, Monitoring Aktifitas Siswa.

Hasil penelitian menunjukkan bahwa E-learning Madrasah memiliki banyak keunggulan yang dirancang oleh Kementerian Agama, seperti mudah diakses 
dimanapun dan kapanpun. Fitur juga menunjukkan bahwa dapat digunakan pembelajaran Bahasa Arab yang mencakup empat maharoh. Dengan keamanan yang bagus (melalui username dan password masing-masing yang berbeda-beda), diharapkan kegiatan pembelajaran bahasa Arab dapat terprogram secara mandiri dengan menggunakan akses internet secara efektif sehingga pembelajaran tetap berlangsung dalam kondisi pandemic dalam pantauan langsung dari Kementerian Agama, Madrasah, Pendidik dan Orang Tua Pendidik.

\section{Daftar Rujukan}

Alim, Adam Ahmad Syahrul, and Abdulloh Hamid. "Efektivitas Sistem E-Learning Quipper School Pada Mata Pelajaran Bahasa Arab Kelas X MA Ihyaul Ulum Gresik." Al-Fikr: Jurnal Pendidikan Islam 6, no. 1 (2020): 34-39.

Anggito, Albi, and Johan Setiawan. Metodologi Penelitian Kualitatif. CV Jejak (Jejak Publisher), 2018.

Chandrawati, Sri Rahayu. "Pemanfaatan E-Learning Dalam Pembelajaran." Jurnal Cakrawala Kependidikan 8, no. 2 (2010): 218616.

Dahiya, Shashi, Seema Jaggi, K. K. Chaturvedi, Anshu Bhardwaj, R. C. Goyal, and Cini Varghese. "An ELearning System for Agricultural Education." Indian Research Journal of Extension Education 12, no. 3 (2016): 132-35.

Effendi, Empy, and Hartono Zhuang. E-Learning Konsep Dan Aplikasi. Yogyakarta: Penerbit Andi, 2005.

https://elearning.kemenag.go.id/. "E-Learning Madrasah Official." Accessed December 29, 2020. https://elearning.kemenag.go.id/web.

Keengwe, Jared, and David Georgina. "The Digital Course Training Workshop for Online Learning and Teaching." Education and Information Technologies 17, no. 4 (2012): 365-79.

Putry, Hesty Maulida Eka, Venia Nuzulul'Adila, Rofiatus Sholeha, and Danial Hilmi. "Video Based Learning Sebagai Tren Media Pembelajaran Di Era 4.0." Tarbiyatuna: Jurnal Pendidikan Ilmiah 5, no. 1 (2020): 1-24.

Rohmah, Lailatu. "Konsep E-Learning Dan Aplikasinya Pada Lembaga Pendidikan Islam." An-Nur: Jurnal Studi Islam 3, no. 2 (2016). 
Siti Nurul Fitriani, Syarifah, Ali Susanto

Sanaky, Hujair AH. Media Pembelajaran. Yogyakarta: Safiria Insania Press, 2009.

Siahaan, Sudirman. "Penelitian Penjajagan Tentang Kemungkinan Pemanfaatan Internet Untuk Pembelajaran Di SLTA Di Wilayah Jakarta Dan Sekitarnya." Jurnal Pendidikan Dan Kebudayaan. Halaman, 2002, 784-808.

Sudaryanto, Dwi Heri. "Pemanfaatan E-Learning Sebagai Media Pembeljaran Mandiri." Swara Patra 6, no. 4 (2016).

Tambunan, Hamonangan. "Pemanfaatan E-Learning Dalam Pembelajaran.” Jurnal Teknologi Pendidikan 4, no. 01 (2011): 104-13. 